\title{
引抜試験に基づく大口径圧縮型地盤アンカーの摩擦応力度評価 EVALUATION OF FRICTIONAL STRESS OF COMPRESSIVE TYPE GROUND ANCHOR
WITH A LARGE DIAMETER BASED ON PULLING TESTS
}

森 利 弘 $^{* 1}$, 遠 藤 正 美*1

Toshihiro MORI and Masaharu ENDO

\begin{abstract}
The ground anchor used mainly in the building structure and in the construction of earth retaining for excavation is the friction resistance type. However, it can't be said that the characteristics of that type of frictional stress are well understood. Here, we conducted the pulling tests on ground anchor of compression type with a large diameter which is also the frictional resistance type. Based on the results, we clarified the characteristics of frictional stress of that anchor in the process of pull-out and after pull-out, including the evaluation of ultimate friction stress and residual friction stress.
\end{abstract}

\section{Keywords : Ground anchor, Pulling test, Friction resistance, Bond resistance} 地盤アンカー, 引抜試験, 摩擦抵抗, 付着抵抗

\section{1. はじめに}

建築物あるいは山留め工事において主に採用されている地盤アン カーは摩擦抵抗型のアンカーであり, 円筒状に造成された抵抗体(定 着体）と地盤との摩擦抵抗によって引張荷重に抵抗する。このよう な摩擦抵抗型の地盤アンカーにおける引張材から定着体への荷重伝 達方式には, 定着体区間における引張材と注入材との付着抵抗によ って伝達する方式 (Fig.1(a)), あるいは引張材先端に設けた耐荷体 と注入材との付着抵抗によって伝達する方式 (Fig.1(b)) に大別さ れる. 本アンカーは後者に分類され，アンカー頭部に作用する引張 荷重はアンボンド加工した引張材を通して, 定着体先端から上方に 定着体を押し上げるように作用する。このため, 注入材は引張荷重

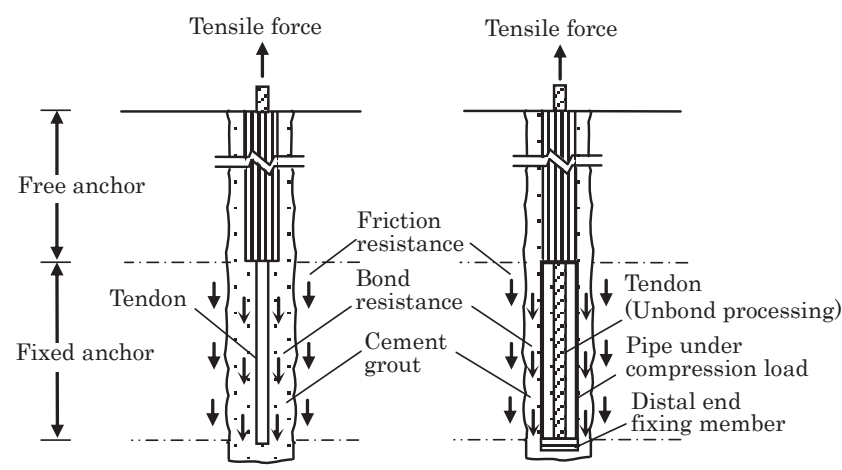

(a)Bond resistance between tendon and cement grout

(b)Bond resistance between pipe and cement grout
作用時に圧縮状態となり, このような地盤アンカーは分類上, 圧縮 型地盤アンカーと呼ばれている 11 . 圧縮型地盤アンカーではポアソ ン比効果により定着体に作用する地盤の側圧（拘束圧）が荷重作用 時に増加するという特長がある。一方, Fig.1 (a)の引張材と注入材 との付着抵抗による伝達方式では定着体上端から引張荷重が作用し, 定着体区間における引張材周囲の注入材は引張状態となることから, このような地盤アンカーは分類上, 引張型地盤アンカーと呼ばれて いる 1). 引張型地盤アンカーでは圧縮型地盤アンカーと異なり，荷 重作用時に定着体に作用する地盤の側圧（拘束圧）は逆に減少する という相違がある。

摩擦抵抗型地盤アンカーにおける摩擦応力度の評価事例として, 参考文献 2)では過去に行われた引抜試験結果を基に，極限摩擦応力 度 $\tau_{\mathrm{u}}$ と定着地盤 $\mathrm{N}$ 值との関係が整理されている. 定着地盤の種類 として, 砂質土地盤・砂碟地盤と粘性土地盤の 2 種類に分けて $\tau \mathrm{u}$ と $\mathrm{N}$ 值の回帰式が求められており, 両地盤ともに同じ $\tau_{\mathrm{u}} \fallingdotseq 18 \mathrm{~N}$ $\left(\mathrm{kN} / \mathrm{m}^{2}\right)$ が得られている.ただし, 試験データは引張型地盤アンカ 一におけるデータであり, 本アンカーのような圧縮型地盤アンカー におけるデータは含まれていない, 一方, 圧縮型地盤アンカーに関 して, 桂ら 3)は同じく引抜試験結果から， $\tau$ u と $\mathrm{N}$ 值の関係を整理 し， $\tau_{\mathrm{u}}$ は引張型地盤アンカーより大きく， $\tau_{\mathrm{u}}=18 \mathrm{~N}$ が概ね下限值 となっていることを報告している。ただし，これらの引張型および 圧縮型地盤アンカーに関する $\tau$ u 評価事例ではともに $\mathrm{N}$ 值との関 係でて u を評価しているため, 非常にばらつきが大きい結果となり, $\mathrm{N}$ 值の増加に伴い摩擦応力度が大きくなるという定性的な傾向は伺

Fig. 1 Load transfer method from tendon to fixed anchor in the friction resistance ground anchor 
Table1 List of test anchor

\begin{tabular}{|c|c|c|c|c|c|c|c|c|c|c|c|}
\hline \multirow[b]{2}{*}{$\begin{array}{l}\text { Tset } \\
\text { anchor } \\
\text { No. }\end{array}$} & \multirow[b]{2}{*}{ Test name } & \multirow[b]{2}{*}{$\begin{array}{l}\text { Diameter } \\
\text { of drilling } \\
(\mathrm{mm})\end{array}$} & \multicolumn{3}{|c|}{ Fixing strata profile } & \multirow[b]{2}{*}{$\begin{array}{l}\text { Fixed anchor } \\
\text { length } \\
(\mathrm{m})\end{array}$} & \multirow[b]{2}{*}{$\begin{array}{l}\text { Outer diameter/ } \\
\text { inner diameter } \\
\text { of pipe }\end{array}$} & \multirow[b]{2}{*}{$\begin{array}{c}\text { Tendon } \\
\text { (Unbond PC } \\
\text { steel strand) }\end{array}$} & \multicolumn{3}{|c|}{ Grout } \\
\hline & & & Soil type & $\begin{array}{l}\text { SPT-N } \\
\text { value }\end{array}$ & $\begin{array}{c}\mathrm{Py}^{{ }^{*} 1} \text { or cu }{ }^{{ }^{2} 2} \\
\left(\mathrm{kN} / \mathrm{m}^{2}\right)\end{array}$ & & & & $\begin{array}{l}\mathrm{W} / \mathrm{C} \\
(\%)\end{array}$ & $\begin{array}{c}\text { Compression } \\
\text { strength } \\
\left(\mathrm{N} / \mathrm{mm}^{2}\right) \\
\end{array}$ & $\begin{array}{c}\text { Elastic } \\
\text { coefficient } \\
\mathrm{Ec}\left(\mathrm{kN} / \mathrm{mm}^{2}\right)\end{array}$ \\
\hline 1 & Pull-out test & \multirow{4}{*}{225} & Gravel & 59 & $\mathrm{P}_{\mathrm{y}}=2.65 \times 10^{3}$ & 1.0 & \multirow{4}{*}{$\phi 152 / 116$} & \multirow{4}{*}{$\begin{array}{c}6^{-} \phi 21.8 \\
\left(\mathrm{~T}_{\mathrm{sy}}{ }^{* 3}=2,970 \mathrm{kN}\right)\end{array}$} & 50 & 42.8 & 15.0 \\
\hline 2 & Pull-out test & & Sand & 56 & $\mathrm{P}_{\mathrm{y}}=1.45 \times 10^{3}$ & 1.0 & & & 50 & 49.4 & 14.6 \\
\hline 3 & Pull-out test & & Silt rock & 138 & $\mathrm{cu}=1.70 \times 10^{3}$ & 1.0 & & & 50 & 31.4 & 13.0 \\
\hline 4 & Pull-out test & & Tuff rock & 250 & $\mathrm{cu}=3.84 \times 10^{3}$ & 1.0 & & & 50 & 70.5 & 16.7 \\
\hline
\end{tabular}

*1: The $\mathrm{P}_{\mathrm{y}}$ is the value of yield pressure in borehole horizontal load test

$* 2$ : The $c u$ is the undrained shear strength and is determined as $q u / 2$

*3: The Tsy is the standard yield load of strand

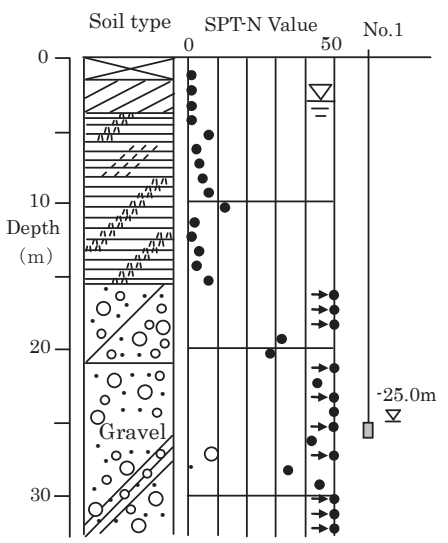

えるが，摩擦応力度の評価は必ずしも十分ではないと言える.

筆者らは大口径圧縮型地盤アンカーの開発時に実施した引抜試験 等の結果から, 本アンカーの摩擦抵抗特性について検討してきた ${ }^{4)}$ ）．例えば，引抜試験結果を基に，c， $\phi$ による極限摩擦応力度の 評価を行っているが，引抜き以降における摩擦応力度の評価など未 解明な点も残されていた。そこで，本報では引抜き以降における摩 擦応力度と変位の関係, 残留摩擦応力度の検討を行うことにより, 大口径圧縮型地盤アンカーの引抜きに至る過程から引抜き以降まで の摩擦応力度の特性を明らかにした。なお, 引抜きとは載荷時に荷 重が低下し，アンカー頭部変位が急増する状態を言うこととする.

本アンカーにおける定着体の直径は一般的に用いられている地盤 アンカーの直径（115 170mm）より一回り大きい $225 \mathrm{~mm}$ である ことから，大口径地盤アンカー（または大口径）と称す，また，本 報では引抜きに至っていない試験データについても参照しているが, 試験における摩擦応力度の最大值を最大摩擦応力度と呼び，引抜き に至った場合で概ねピーク值となっている場合には, 破壊モード(定 着体と地盤との摩擦切れまたは耐荷体と注入材との付着切れ）に関 係なく, その最大值を極限摩擦応力度と見なすこととする.

\section{2. 引抜試験の概要}

\section{1 試験アンカー}

試験アンカーの一覧を Table 1 に示す. 本アンカーは定着体に耐 荷体 (リブ付鋼管), 引張材にアンボンド PC 鋼より線を用いた圧縮 型地盤アンカーである ${ }^{4}$. 試験アンカーにおける削孔角度は $90^{\circ}$ (鋁 直), 削孔径 (=定着体径) は $\phi 225 \mathrm{~mm}$, 定着体の長さは $1 \mathrm{~m}$ であ る。なお，本アンカーでは耐荷体の長さは定着体の長さに等しい.

試験を行った敷地における土質柱状図と定着体深度の関係を Fig . 2 に示す. 試験アンカーの定着地盤は, 砂磎, 砂, シルト岩, 凝灰 岩の 4 種類とした。これらの定着地盤のうち，シルト岩は土丹など
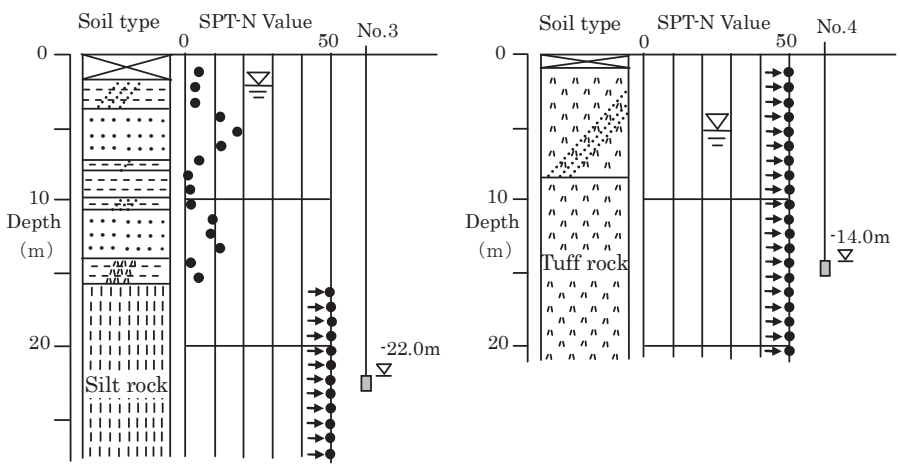

(Upper side)

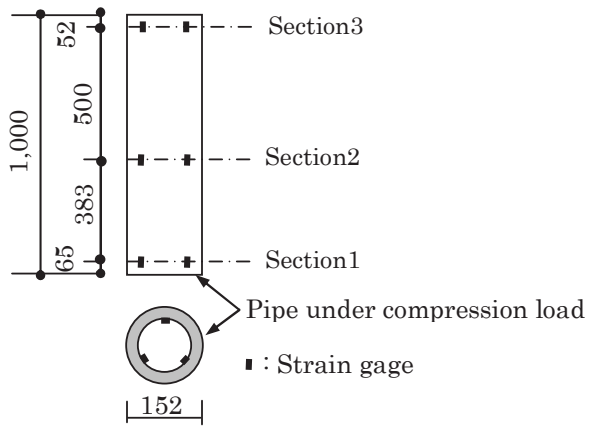

Fig. 3 Installation position of strain gage (Unit:mm)

の硬質粘土，また，凝灰岩は軟岩を想定したものである．Table 1 に 示すとおり，各定着地盤の $\mathrm{N}$ 值（60 を超える場合は換算 $\mathrm{N}$ 值）は すべて 50 以上である.

試験アンカーの削孔方法は, 定着地盤が砂礫と砂の場合にはケー シングロッドとインナーロッドによる二重管掘り, シルト岩と凝灰 岩の場合にはケーシングロッドによる単管掘りとし, 注入方式はア ンカー部材挿入後に注入材（ $\mathrm{W} / \mathrm{C}=50 \%$ のセメントペースト）を注 入する後行注入方式としている. セメントペーストの注入後, ケー シングを $1 \mathrm{~m}$ 引抜き, 定着体上端梁度においてケーシング加圧注入 (口元圧力 $500 \mathrm{kN} / \mathrm{m}^{2}$ を 5 分保持）を実施している. 試験アンカー 施工時に採取した注入材オーバーフロー液の引抜試験当日における 圧縮強度は設計強度である $30 \mathrm{~N} / \mathrm{mm}^{2}$ を上回っている（Table1）。

\section{2 試験方法}

引抜試験における載荷方法は，300kN を初期荷重とし，原則 200 $\mathrm{kN}$ を荷重段階とする多サイクル方式を採用している。荷重保持時 間は新規荷重時では 10 分であるが, 計画最大荷重時は 30 分, 履歴 内荷重時は 2 分としている. なお, 計画最大荷重は引張材の規格降 伏荷重 $\mathrm{T}_{\mathrm{sy}}$ の約 9 割である $2670 \mathrm{kN}$ としている. 計測項目は, ジャ 
ッキ荷重（圧力変換器による荷重）に加え，地表面位置におけるア ンカー頭部の鉛直変位 (変位計による引張材の鉛直変位), 耐荷体の 軸方向ひずみ（ひずみゲージによる軸ひずみ）である．Fig.3に耐 荷体に設置したひずみゲージの位置を示す。ひずみゲージは 3 深度 (断面）とし，各断面においては円周方向に均等に設置した.

載荷装置は反力杭方式 4)とし，センターホールジャッキを用い， 引抜き載荷を荷重制御で行った。なお，試験体 No.4の場合，地表 付近より凝灰岩が出現することから, 載荷装置は反力板方式とした.

\section{3. 引抜きに至るまでのアンカー挙動}

\section{1 アンカー頭部における荷重変位の関係}

後掲する引抜き以降を含め, アンカー頭部における荷重変位の関

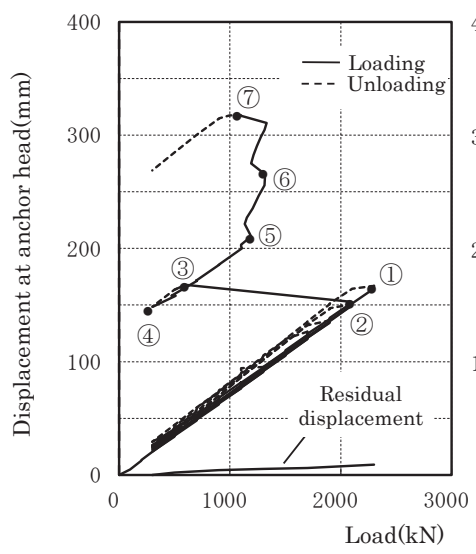

(a)Gravel

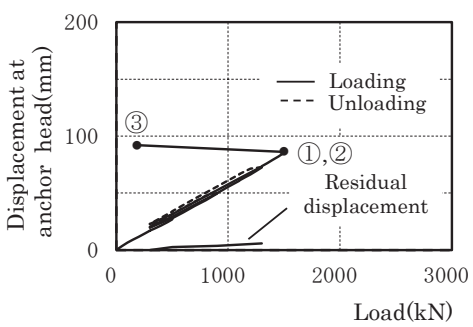

(b)Sand

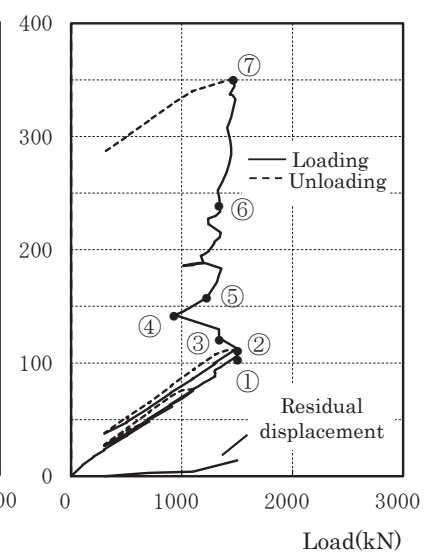

(c)Silt rock

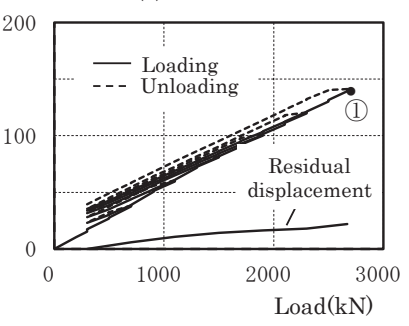

(d)Tuff rock
Fig. 4 Relationship between displacement at anchor head and load

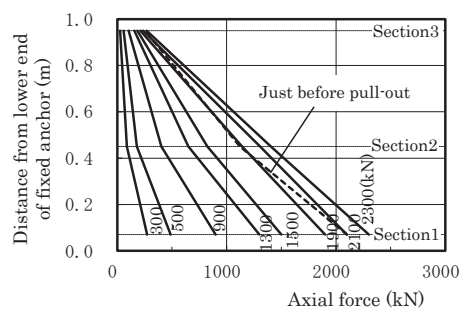

(a)Gravel

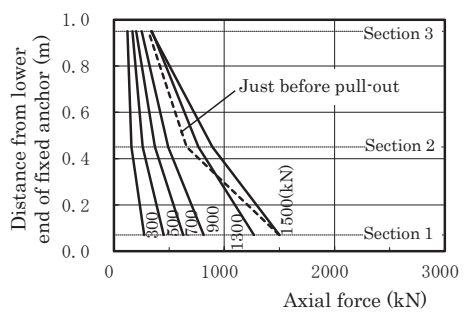

(b)Sand

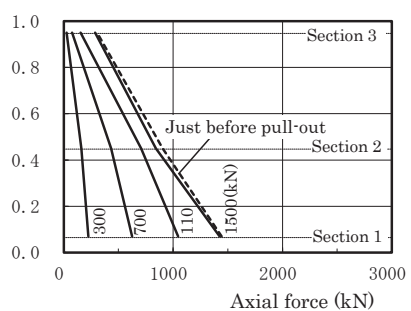

(c)Silt rock

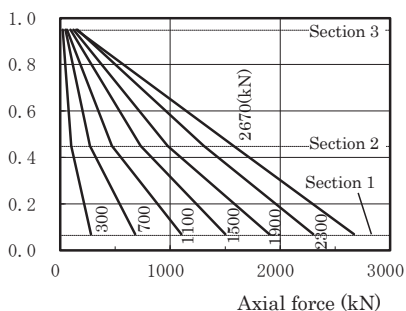

(d)Tuff rock
Fig. 5 Distribution of axial force of fixed anchor
係を Fig.4 に示す. 図中の(1)は最大荷重時, (2) は引抜きに至る直前, (3)は引抜き直後, (4)〜 (7) は引抜き以降における載荷時を示寸.なお, これらのうち，64耐荷体ひずみが計測できた最終計測時を示す. また, 図中に示した残留変位量は, 各サイクルの最大荷重時から各 サイクルにおいて初期荷重まで戻した時の残留変位の值を示す.

砂礫地盤に定着した場合，新規荷重 $2300 \mathrm{kN}$ （Fig.4(a)の(1)）の載 荷後, 次サイクルの履歷内荷重 $2100 \mathrm{kN}$ （同(2)）の荷重保持 2 分を 行った直後に「ドーン」という音とともに変位が急増, 荷重は $610 \mathrm{kN}$ （同(3）に低下し，引抜きに至った。最大荷重 $2300 \mathrm{kN}$ に対して， 引抜き時の荷重は $2100 \mathrm{kN}$ である。また，砂地盤に定着した場合， 新規荷重 $1500 \mathrm{kN}$ （Fig.4(b)の(2)）の荷重保持中に「ドーン」という 音とともに変位が急増，荷重は $200 \mathrm{kN}$ （同(3)）に低下し，引抜きに 至った。

一方，シルト岩に定着した場合には，新規荷重 $1500 \mathrm{kN}$ （Fig.4(c) の1) の載荷を行った後, 次サイクルでの履歴内荷重 $1500 \mathrm{kN}$ （同 (2)）の荷重保持中に $1500 \mathrm{kN}$ が保持できなくなり，荷重は $1350 \mathrm{kN}$ （同(3)）に低下し，引抜きに至った。引抜き時には「ドーン」とい う音は発生していない。なお，凝灰岩に定着した場合には計画最大 荷重 $2670 \mathrm{kN}$ （Fig.4(d)の１）まで）順調に載荷でき，引抜きには至ら なかった.

各試験体におけるアンカー頭部の荷重変位は引抜きに至るまでほ ぼ線形関係にあり,引抜きに至る兆候は事前には見られない. また, 残留変位量について見るとシルト岩では引抜き時に微増するが，他 の定着地盤では荷重増加に伴い, 徐々に増加する傾向を示し, 残留 変位からも引抜きに至る兆候は確認されなかった。

\section{2 摩擦応力度と荷重の関係}

耐荷体に設置したひずみゲージの值から，式(1)により定着体の各 断面における軸方向力（圧縮力）を算定し，式(2)から定着体と地盤 間の摩擦応力度を算定した.

式(1)に示寸ように, 定着体の軸方向力は耐荷体の軸方向力と注入 材の軸方向力の和とし，耐荷体ひずみから耐荷体軸方向力への換算 は事前に実施したアムスラー式万能試験機による荷重と耐荷体ひず みの校正值を用いて行っている。また，注入材の軸方向力は耐荷体

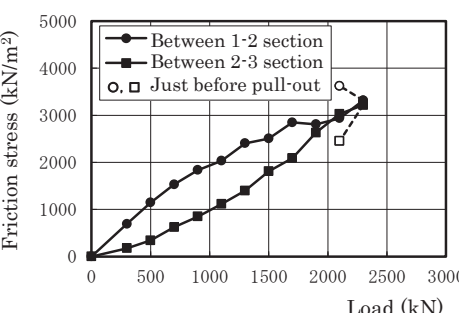

(a)Gravel

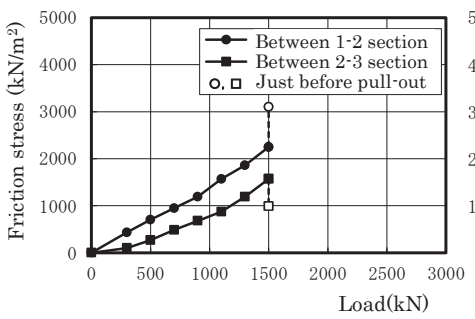

(b)Sand

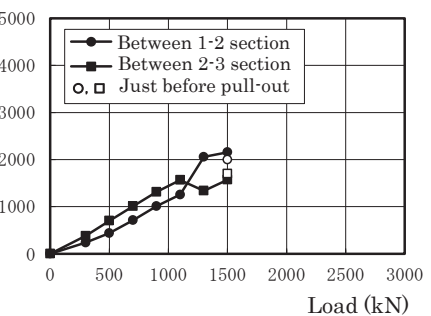

(c)Silt rock

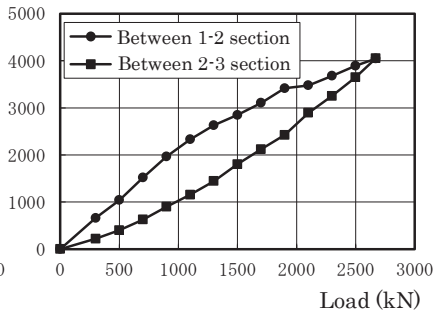

(d)Tuff rock
Fig. 6 Relationship between friction stress and pull-out load 
と注入材が平面保持していると仮定し，耐荷体ひずみから式(1)を用 いて算定している，なお，定着体の軸方向力は載荷荷重を上限值と した.

$$
\mathrm{P}=\mathrm{P}_{\mathrm{s}}(\varepsilon)+\mathrm{E}_{\mathrm{c}} \mathrm{A}_{\mathrm{c}} \varepsilon
$$

記号， $\mathrm{P}$ : 定着体軸方向力 $(\mathrm{kN})$

\section{$\mathrm{P}_{\mathrm{s}}(\varepsilon)$ ：耐荷体軸方向力 $(\mathrm{kN})$}

$\mathrm{E}_{\mathrm{c}}$ : 注入材の弾性係数 $\left(\mathrm{kN} / \mathrm{mm}^{2}\right)$

$\mathrm{A}_{\mathrm{c}}$ : 注入材の断面積 $\left(=2.152 \times 10^{4} \mathrm{~mm}^{2}\right)$

$\varepsilon:$ 而荷体の圧縮ひずみ

$$
\tau=\frac{\mathrm{P}_{\mathrm{i}}-\mathrm{P}_{\mathrm{i}+1}}{\pi \mathrm{D} \ell_{\mathrm{i} \sim \mathrm{i}+1}}
$$

記号, $\tau$ : 定着体と地盤との摩擦応力度 $\left(\mathrm{kN} / \mathrm{m}^{2}\right)$

$$
\begin{aligned}
& \mathrm{P}_{\mathrm{i}}: \mathrm{i} \text { 断面の定着体の軸方向力 }(\mathrm{kN}) \\
& \mathrm{D}: \text { 定着体径 }(=0.225 \mathrm{~m}) \\
& \ell_{\mathrm{i} \sim \mathrm{i}+1}: \mathrm{i} \sim \mathrm{i}+1 \text { 断面間の長さ }(\mathrm{m})
\end{aligned}
$$

各荷重段階における定着体の軸方向力分布を Fig. 5 に, 摩擦応力 度と載荷荷重の関係を Fig.6 に示す. 軸方向力および摩擦応力度の 值は新規荷重時における值（荷重保持終了時）である，なお，す心゙ ての定着地盤において荷重保持中での摩擦応力度の值に顕著な変動 は見られなかった。

Fig.6 に示すようにシルト岩を除くと, 定着体下部側 (1-2 断面間) の摩擦応力度が上部側（2-3 断面間）の值より大きい状態で推移し ている. 砂磖の場合, 引抜きの直前に両者の值が等しくなり, 引抜 きに至っているのに対して, 砂の場合には下部側の值が少し大きい 状態で引抜きに至っている，凝灰岩に定着した場合，砂磁の場合と 類似した傾向が見られることから，引抜きには至っていないが，摩 擦応力度は極限に近い状態であったと推察される。一方, シルト岩 に定着した場合，下部側の摩擦応力度が少し小さい状態で推移し， 引抜き時は上部側の值と概ね等しくなり, 引抜きに至っている.

前記のように引抜きに至るまでの摩擦応力度の挙動は定着地盤毎 に若干異なる。これは定着長 $1 \mathrm{~m}$ 間における地盤強度あるいは地盤 剛性にばらつきが見られることに起因していると考えられるが,

Fig. 5 および Fig. 6 から, 摩擦応力度の共通した挙動として, 載荷の 初期には定着体下部側の值が上部側の值よりも大きい状態で推移し, 両者が概ね等しくなり, 引抜きに至っている。したがって, 以降で は Fig.15 老除き, 定着長 $1 \mathrm{~m}$ 間の平均摩擦応力度を用いて検討寸る こととする.

\section{3 摩擦応力度と変位の関係}

各定着地盤における摩擦応力度と定着体変位の関係を Fig.7 に示 す，定着体変位は，アンカー頭部変位（PC 鋼より線変位）から引 張材の弾性伸び量を差し引いて, アンカー先端（定着体下端）にお ける変位を算定し, さらに定着体の圧縮変形量を考慮した式(3)で算 定している。 なお，定着体变位は概称定着体の中間深度である 2 断 面位置（Fig. 3 参照）での変位を採用した．

$$
\delta=\delta_{\text {頭 }}-\delta_{\text {引 }}-\delta_{\text {耐 }}
$$

記号, $\delta$ : 定着体変位 $(\mathrm{mm})$

$$
\begin{aligned}
\delta_{\text {頭 }} & \text { アンカー頭部変位 }(\mathrm{mm}) \\
\delta_{\text {引! }}: \text { 引張材弾性伸び量 }(\mathrm{mm}) & \\
& (=\mathrm{P} \ell / \mathrm{EA}, \mathrm{P}: \text { 引抜荷重, } \ell: \text { 引張材の自由長, }
\end{aligned}
$$

\section{$\mathrm{E}, \mathrm{A}:$ 引張材の弾性係数, 断面積)}

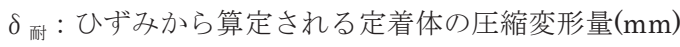
(=而荷体歪 $\varepsilon \times$ 耐荷体長 $\mathrm{L}$ )

Fig.7 には引抜きに至るまでの摩擦応力度と定着体変位の関係を 示しているが，アンカー引抜き時の変位はいずれの定着地盤も $10 \mathrm{~mm}$ 程度となっている. 引抜き時における定着体 $1 \mathrm{~m}$ 間での圧縮 変形量は各定着地盤で多少異なるが, 僅かに $0.35 \sim 0.65 \mathrm{~mm}$ であり, 定着体は概初剛体として挙動している。 一方, 各定着地盤における 摩擦応力度と変位の関係にはシルト岩と他の定着地盤では少し差異 が見られる。すなわち，定着地盤がシルト岩の場合にはバイリニア 型に近い挙動を示しているのに対して他の定着地盤では初期変位の 段階から非線形性が生じる双曲線型の挙動を示している. Fig.8 に は載荷荷重と各荷重保持中におけるアンカー頭部クリープ変位の関

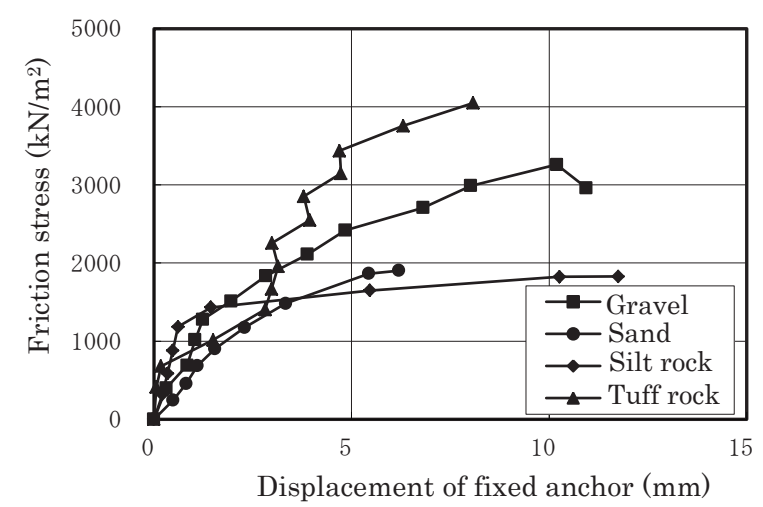

Fig. 7 Relationship between friction stress and displacement of fixed anchor

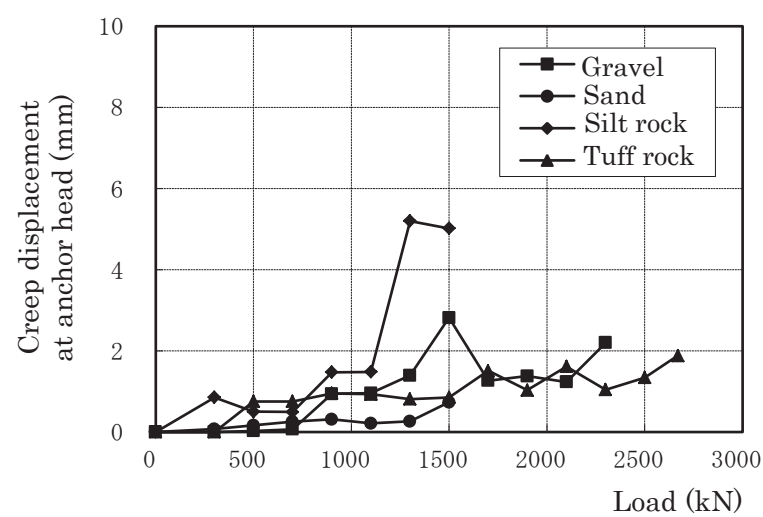

Fig. 8 Relationship between creep displacement at anchor head and load

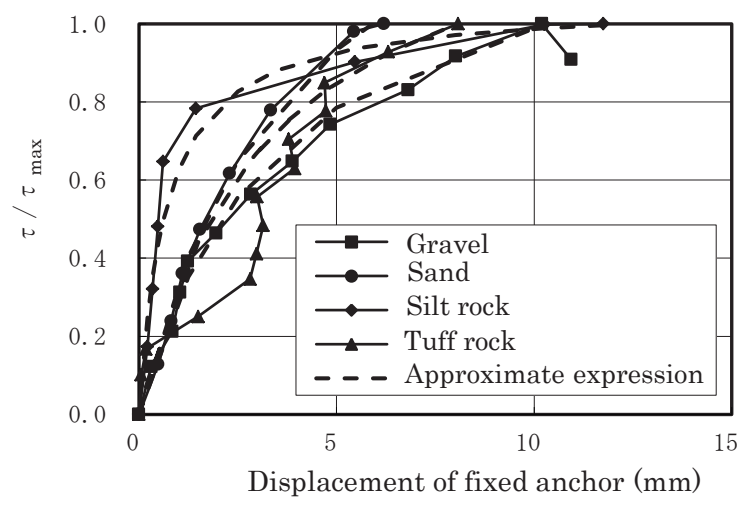

Fig. 9 Relationship between $\tau / \tau_{\max }$ and displacement of fixed anchor 
Table2 Calculation result of approximate expression

\begin{tabular}{|c|c|c|c|c|}
\hline \multirow{2}{*}{ Soil type } & \multicolumn{2}{|c|}{$\tau / \tau \max =\delta /(\mathrm{a}+\mathrm{b} \cdot \delta)$} & \multirow{2}{*}{$\tau \max \left(\mathrm{kN} / \mathrm{m}^{2}\right)$} \\
\cline { 2 - 4 } & Value of a & Value of $\mathrm{b}$ & Range of $\delta$ & \\
\hline Gravel & 2.62 & 0.75 & $\delta \leqq 10 \mathrm{~mm}$ & $3.26 \times 10^{3}$ \\
\hline Sand & 2.34 & 0.60 & $\delta \leqq 6 \mathrm{~mm}$ & $1.90 \times 10^{3}$ \\
\hline Silt rock & 0.65 & 0.95 & $\delta \leqq 12 \mathrm{~mm}$ & $1.83 \times 10^{3}$ \\
\hline Tuff rock & 2.34 & 0.71 & $\delta \leqq 8 \mathrm{~mm}$ & $4.05 \times 10^{3}$ \\
\hline
\end{tabular}

係を示しているが，定着地盤がシルト岩の場合には引抜きに至る荷 重の直前においてクリープ変位が急増しており, 他の定着地盤との 挙動の違いはクリープ特性の差であると考えられる.

摩擦応力度 $\tau$ を各定着地盤における最大摩擦応力度 $\tau$ max た值（ $\tau / \tau \max ）$ と定着体変位 $\delta$ の関係を Fig.9 に示す. Fig.9 に示 すように $\tau / \tau$ max と変位 $\delta$ の関係はシルト岩を除くと概ね類似して いることが読み取れる。ここで，定着体と地盤との間の摩擦ばねの モデル化について検討する。摩擦ばねのモデル化として摩擦応力度 が最大值に達するまでの間を, 式(4)に示す双曲線モデル7で近似す る.式(4)における係数 a,b は, 共通の代表点変位 $(1.25 \mathrm{~mm}, 2.5 \mathrm{~mm}$, $5 \mathrm{~mm} ）$ および各定着地盤での引抜き時変位における $\delta /(\tau / \tau$ max $)$ と $\delta$ の関係を求め, 各点を直線回帰して求めた ${ }^{8)}$.

$$
\tau / \tau \max =\delta /(\mathrm{a}+\mathrm{b} \cdot \delta)
$$

記号， $\mathrm{a}, \mathrm{b}$ : 係数, $\delta$ : 定着体変位 $(\mathrm{mm})$

Table2 に各定着地盤における摩擦げね近似式の算定結果, 前述し た Fig.9 に試験結果と比較した摩擦ばね近似式（破線）を示す．各 定着地盤における摩擦ばねは式(4)による双曲線で近似できること, シルト岩を除いた近似式は概ね類似していることが分かる.

なお, Fig.7および Fig.9 の凝灰岩において, 摩擦応力度増加時に 変位が僅かに減少している箇所が見られるが，これは多少イクル方 式で載荷を行った際に各サイクルで生じた引張材の回転が影響して いると考えられる.

\section{4 最大摩擦応力度と $\mathrm{N}$ 值の関係}

Fig.10 は最大摩擦応力度と $\mathrm{N}$ 值との関係を示したものである.困 中には本アンカーの引張試験 ${ }^{6}$ )における值（定着体先端 $1 \mathrm{~m}$ 間での 摩擦応力度）に加え, 既往の一般口径アンカー（ $\phi 170 \mathrm{~mm})$ での值 4),5)を追記している. 定着地盤の分類は, 砂磁, 砂, 土丹等の硬質 粘土（洪積粘土を含む），軟岩の 4 種類とし，シルト岩は硬質粘土， 凝灰岩は軟岩に分類している. 最大摩擦応力度と $\mathrm{N}$ 值の関係につい て見ると同一 $\mathrm{N}$ 值に対する最大摩擦応力度にはばらつきが大きい ことが読み取れる.これは参考文献 2)における極限摩擦応力度と $\mathrm{N}$ 值との関係の場合と同様である。 また，図中に示した $\tau_{\mathrm{u}}=28 \mathrm{~N}(\mathrm{~N}$ は $\mathrm{N}$ 值，ただし，ここでは $2800 \mathrm{kN} / \mathrm{m}^{2}$ を上限值）は砂層での引抜 きに至った一般口径アンカーでの極限摩擦応力度と $\mathrm{N}$ 值の回帰式 ${ }^{4)}$ であるが，砂層を含め，全定着地盤に対しても概ね中間值となって いることが分かる．なお， $\mathrm{N}$ 值 100 を超えると全定着地盤ともに最 大摩擦応力度に顕著な増加傾向は見られない。

大口径と一般径との比較について検討する，砂層に定着した大口 径アンカーにおける極限摩擦応力度は, 概称 $\tau_{\mathrm{u}}=28 \mathrm{~N}$ のライン上に あることから，大口径アンカーの砂層における極限摩擦応力度は一 般口径アンカーと同等であると考えることができる．また，砂㗜層 での結果について見ると，一般径で引抜きに至ったアンカー9 ${ }^{9}$ は砂

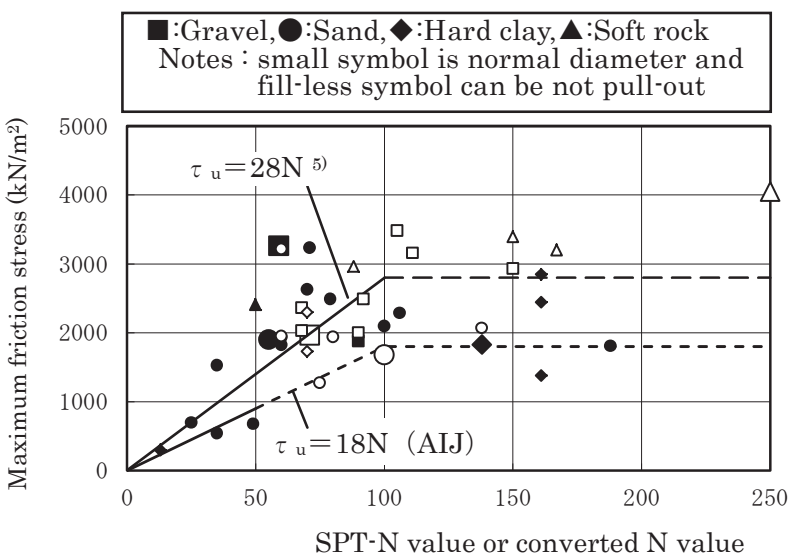

Fig. 10 Relationship between maximum friction stress and SPT-N value

礫層と粘土層との互層地盤に定着した場合のみであり，互層地盤に よる影響が含まれていることから, 直接比較は難しいと考えられる. 一方，硬質粘土の場合，一般口径アンカーでは同じ $\mathrm{N}$ 值でも極限摩 擦応力度にはばらつきが見られるが，それらの平均值と比較すると 大口径アンカーでの值は大差ない結果となっている，なお，軟岩で の值は前述したように極限に近い值であると推定されるが，一般口 径アンカーでの引抜きに至った事例との $\mathrm{N}$ 值に大きな差があるこ とから, 砂碩層と同じく直接比較は難しい.

Fig.10に示した $\tau$ u $=18 \mathrm{~N}\left(\mathrm{~N}\right.$ は $\mathrm{N}$ 值, ただし,ここでは $1800 \mathrm{kN} / \mathrm{m}^{2}$ を上限值）は参考文献 2)における回帰式を示している。一般口径ア ンカーを含め，極限摩擦応力度はその值が概小下限值となっている ことが分かる. また, 参考文献 2)における回帰式 $\tau_{\mathrm{u}}=18 \mathrm{~N}$ は引張型 地盤アンカーにおける試験結果であることを踏まえると本口径アン カーを含め, 圧縮型地盤アンカーでは概ね $\tau$ u $=28 \mathrm{~N}$ であることから， 同一 $\mathrm{N}$ 值に対して約 1.5 倍に極限摩擦応力度が大きくなっている.

\section{$3.5 \mathrm{c} ， \phi に よ る$ 極限摩擦応力度評価}

(1)砂磎地盤または砂地盤に定着した場合

定着体と地盤間の極限摩擦応力度は定着体の表面は粗いことから， 定着体近傍における地盤のせん断強さである式(5)で算定できると 考えられる.

$$
\tau_{u}=\sigma_{h} \tan \phi+c
$$

記号, $\tau_{\mathrm{u}}$ : 極限摩擦応力度 $\left(\mathrm{kN} / \mathrm{m}^{2}\right)$

$\sigma_{\mathrm{h}}$ : 定着体に作用寸る地盤の拘束圧 $\left(\mathrm{kN} / \mathrm{m}^{2}\right)$

$\phi$ : 定着地盤の内部摩擦角 $\left(^{\circ}\right)$

$\mathrm{c}$ : 定着地盤の粘着力 $\left(\mathrm{kN} / \mathrm{m}^{2}\right)$

$$
\tau_{u}=\sigma_{h} \tan \phi=K_{s} \sigma_{z}{ }^{\prime} \tan \phi
$$

記号, $\mathrm{K}_{\mathrm{s}}$ : 側圧係数

$$
\sigma_{z^{\prime}}: \text { 有効上載圧 }\left(\mathrm{kN} / \mathrm{m}^{2}\right)
$$

定着地盤が砂碟または砂の場合, $\mathrm{c}=0\left(\mathrm{kN} / \mathrm{m}^{2}\right)$ とすると式(5)は式 (6)のように, 定着地盤の有効上載圧に側圧係数を乗じて算定できる. そこで，Fig.11には有効上載圧と最大摩擦応力度の関係を示した.

Fig.11に示した值は Fig.9 の一部であるが，一般口径アンカーを含 め，すべて $\mathrm{N}$ 值 50 以上の定着地盤での結果を示している．Fig.11 に示した二つの破線は, $\tan \phi=1$ として求めた $\tau_{\mathrm{u}}$ の算定結果を示 
しているが，そのうち側圧係数 $\mathrm{K}_{\mathrm{s}}=5.83$ の破線は地盤の内部摩擦角 $\phi=45^{\circ}$ としたランンの受働土圧係数による值であり, 一般径を含 めた極限摩擦応力度の下限值に等しい。一方, 側圧係数 $\mathrm{K}_{\mathrm{s}}=15.2$ の 破線は，概初試験值の上限ラインを結んだ值であり，側圧係数 $\mathrm{K}_{\mathrm{s}}=$ 15.2 は $\phi=45^{\circ}$ としたランキンの受働土圧係数 5.83 の 2.6 倍となっ ている.このように有効上載圧との関係で整理する場合も $\mathrm{N}$ 值との 関係で整理する場合と同じくばらつきが大きいことが分かる.

前述したように, 式(6)において $\mathrm{N}$ 值 50 以上の場合, $\tan \phi=1$ と すると, 極限摩擦応力度 $\tau$ u は定着体に作用する地盤の拘束圧 $\sigma \mathrm{h}$ に 等しくなる. 本アンカーは圧縮型地盤アンカーであり, アンカー頭 部に作用する引張荷重は Fig.1 に示したように定着体の下方から押 し上げるように作用するため, 定着体は水平方向に押し拡げられ, 定着地盤の拘束圧は増加する。このような状態を再現させる試験方 法として, 孔内水平載荷試験があり, 極限摩擦応力度はその試験に おける孔内圧の值と関連すると考えられる. そこで, Fig. 12 には最 大摩擦応力度と孔内水平載荷試験における降伏圧の関係を示した。

Fig.12 には Fig.11 に示したアンカーのうち, 孔内水平載荷試験を 実施している試験結果を示しており, 引抜きに至っていないアンカ 一についても参考として示している. 引抜きに至っていないアンカ 一では降伏圧を下回っている場合も見られるが，最大摩擦応力度は 降伏圧と同等であり, 定着地盤が砂碟または砂の場合における極限 摩擦応力度は孔内水平載荷試験における降伏圧を地盤の拘束圧に用 いることにより精度良く推定される.

(2)硬質粘土または軟岩に定着した場合

硬質粘土または軟岩の場合，式(5)において $\left.\phi=00^{\circ}\right)$ とすると式(7) が得られる. そこで, Fig.13には最大摩擦応力度と非排水せん断強 さ $\mathrm{c}_{\mathrm{u}}$ との関係を示した。 なお, 三軸圧縮試験を実施していない場合 には $\mathrm{c}_{\mathrm{u}}=\mathrm{q}_{\mathrm{u}} / 2 （ \mathrm{q}_{\mathrm{u}}$ ：一軸圧縮強さ）としている．Fig.13に示すよう に最大摩擦応力度は定着地盤の非排水せん断強さと同等またはその 值以上となっている。したがって, 定着地盤が硬質粘土または軟岩 の場合における極限摩擦応力度は非排水せん断強さで精度良く推定 される，なお，前述したように硬質粘土に定着した一般径のアンカ 一においては同一 $\mathrm{N}$ 值における試験結果にばらつきが見られる.こ れは土丹層に定着させた場合の同一敷地内における試験結果である が，土丹層における $\mathrm{c}_{\mathrm{u}}$ のばらつきによる影響と考えられる.

$\tau_{\mathrm{u}}=\mathrm{C}$

記号, $\mathrm{c}$ : 定着地盤の粘着力 $\left(\mathrm{kN} / \mathrm{m}^{2}\right)$

\section{4. 引抜き以降におけるアンカー挙動}

\section{1 引抜き以降におけるアンカー頭部の荷重変位関係}

引抜き以降において載荷を実施した砂碩層およびシルト岩での試 験結果について検討する，なお，砂層においては引抜き直後に耐荷 体ひずみの計測が不可能となったことから引抜き以降の載荷は実施 していない.

前掲した Fig.4(a)および Fig.4(c)を参照する，砂䋹地盤では，引 抜き後急激に荷重低下（Fig.4(a)の(2)から (3)）したことから，一旦， 初期荷重である $300 \mathrm{kN}$ (同(4)）に除荷し, 再載荷を行ったところ, 荷重 $1190 \mathrm{kN}$ (同5) で変位が再度急増した. それ以降, 変位 $318 \mathrm{~mm}$ （Fig.4(a)の（7)）までの載荷を行ったところ, 載荷荷重は多少増減

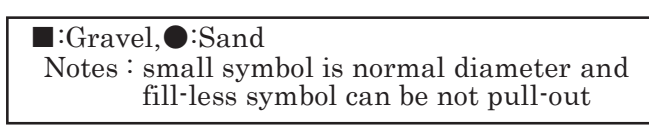

fill-less symbol can be not pull-out

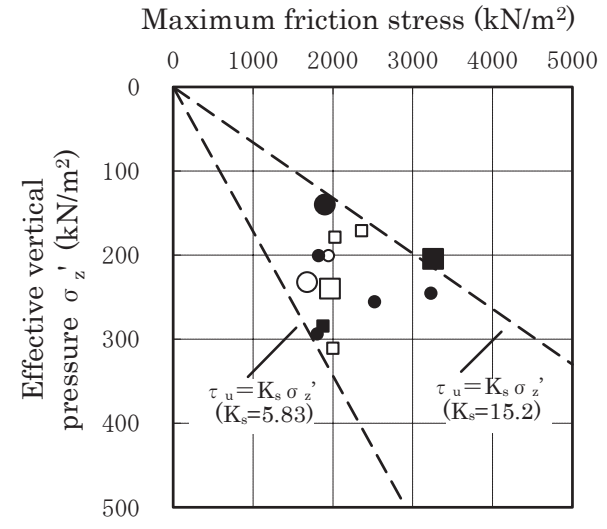

Fig. 11 Relationship between effective vertical pressure and maximum friction stress

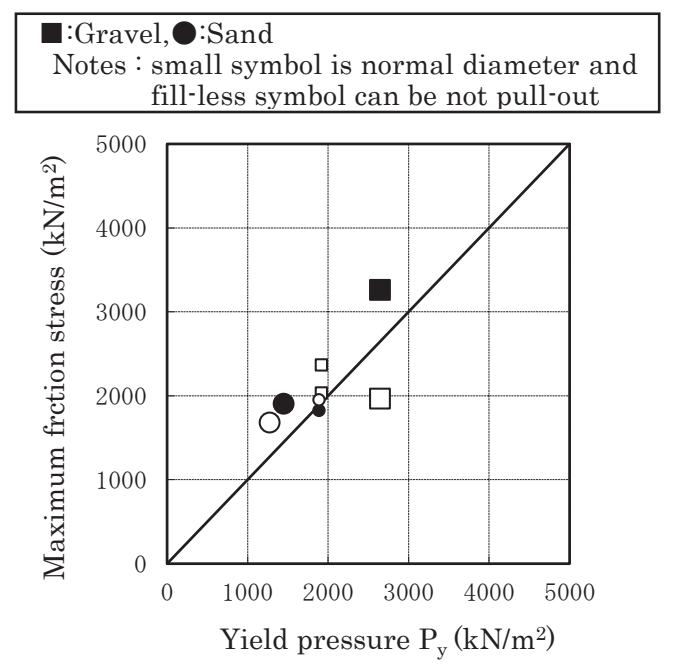

Fig. 12 Relationship between Maximum friction stress and yield pressure in borehole lateral load test

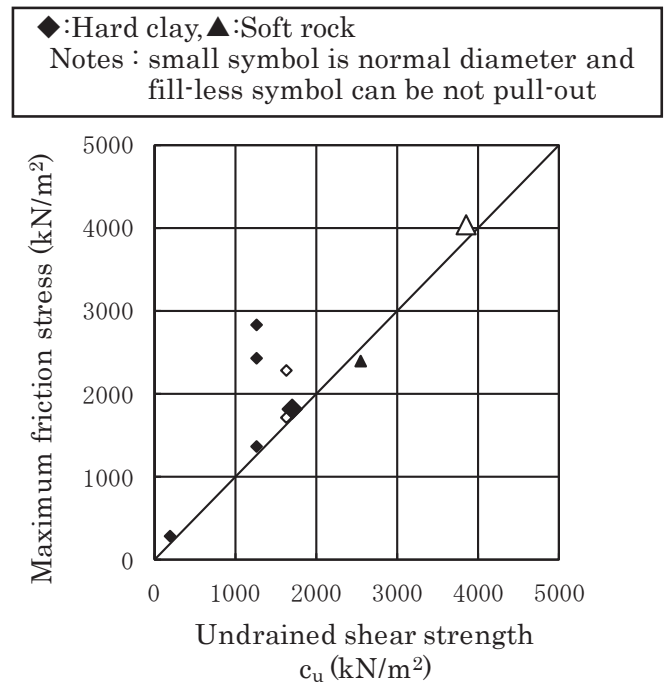

Fig. 13 Relationship between maximum friction stress and undrained shear strength 
するが，載荷荷重に顕著な変化は見られなかった，引抜き時の荷重 $2100 \mathrm{kN}$ に対して最終載荷時の荷重は $1081 \mathrm{kN}$ である.なお, 耐荷体 ひずみが計測できた最終計測值は同図の6の状態である.

一方, シル卜岩では引抜き前後における荷重低下が小さかった （Fig.4(c)の(2)から（3)）ことから，継続して載荷を行った. 載荷後, 一時的に荷重は $940 \mathrm{kN}$ (同(4)）まで低下したが，それ以降，荷重 $1200 \mathrm{kN}$ (同5) で変位が再度急増し始めた。荷重 $1200 \mathrm{kN}$ 以降,

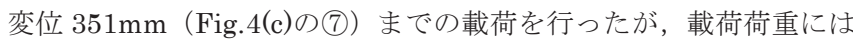
少しずつ増加する傾向が認められる，引抜き時の荷重 $1500 \mathrm{kN}$ に対 して最終載荷時の荷重は $1461 \mathrm{kN}$ である. なお, 耐荷体ひずタが計 測できた最終計測值は同図の6)の状態である.

\section{2 引抜き時における破壊モードの推定}

本アンカーの場合，引抜きに至る破壞モードとして引張材の破断 を除くと, 定着体と地盤との摩擦切れにより引抜きに至る場合と, 耐荷体と注入材との付着切れにより引抜きに至る場合の二つの破壊 モードが存在する．本引抜試験では試験体の掘出し確認を実施して いないため, 最終的に付着切れ之摩擦切れのどちらで引抜きに至っ たか，断定はできないが，ここでは以下のように推定している.

Fig.14 に荷重とアンカー先端（定着体下端）における変位の関係 を示す. アンカー先端における変位は式(3)において $\delta_{\text {耐 }}=0$ とした時 の值であり，Fig.14 には定着地盤が砂層の場合の結果についても参 考として記載している. なお, 引張材にはアンカー全長にわたって アンボンド PC 鋼より線を使用していることから, 荷重には載荷荷重

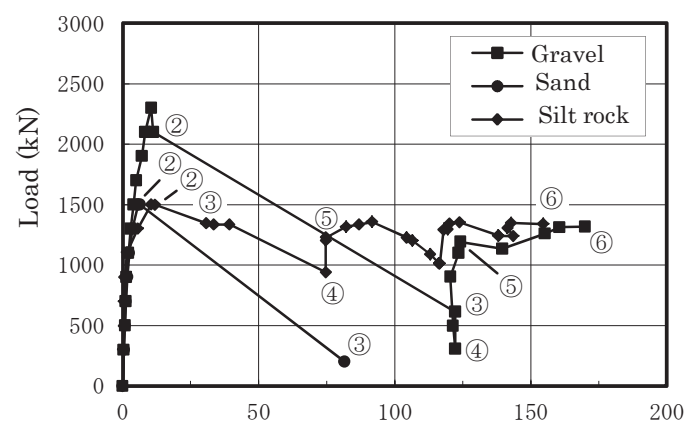

Displacement at distal end of anchor $(\mathrm{mm})$ Fig. 14 Relationship between load and Displacement at distal end of anchor

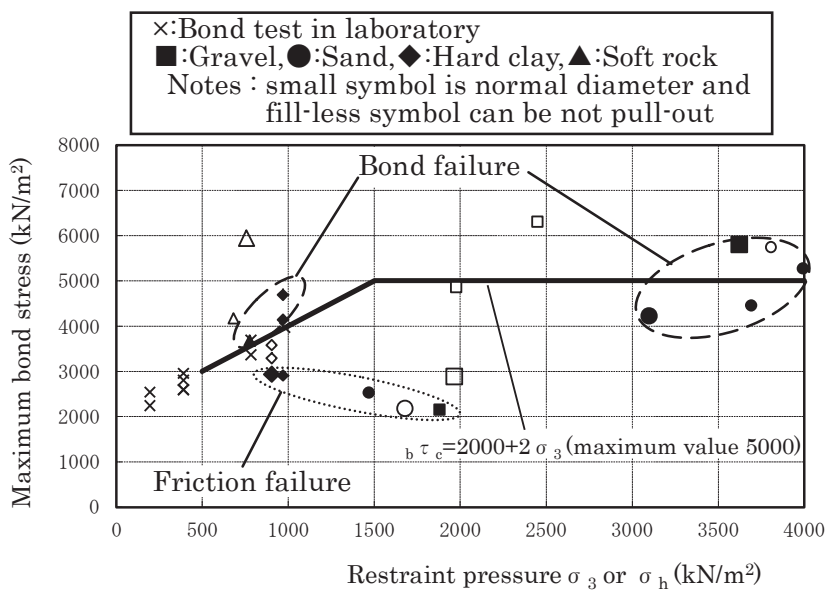

Fig. 15 Relationship between maximum bond stress and restraint pressure
の值を用いている.

定着地盤が砂砂の場合には引抜き前後（Fig.14の(2)と（3)）におい て,「ドーン」という音とともに引抜きに至ったこと, 荷重の急激な 低下に加えて, 定着体下端の変位は $120 \mathrm{~mm}$ 程度急増したことから, 耐荷体と注入材との付着切れにより,引抜きに至ったと推察される. 定着地盤が砂層の場合も同様に付着切れにより，引抜きに至ったと 推察される。一方，シルト岩の場合には「ドーン」という音が発生 しなかったこと, 荷重低下および変位の増加が小さいことから, 定 着体と地盤との摩擦切れにより, 引抜きに至ったと推察される。 な お，定着地盤が砂碟および砂の場合には付着切れにより引抜きに至 ったと考えられるが, 最大摩擦応力度はピーク值（Fig.7 参照）と なっていることから, 摩擦応力度も極限状態にあったと想定される.

本アンカーでは耐荷体と注入材との付着抵抗を高めるために大口 径および一般径ともに耐荷体にはリブ高さ $2 \mathrm{~mm}$, リブピッチ $50 \mathrm{~mm}$ のリブ付鋼管を採用している. 一般径のアンカー開発時に行った室 内付着力試験および原位置での引抜試験から，而荷体と注入材との 極限付着応力度は式(8)で算定できるとしている ${ }^{3)}$. 式(8)に示すよう に極限付着応力度は注入材に作用する拘束圧に依存する. Fig. 15 は 式(8)による值に試験結果を記載した図であり, 縦軸には最大付着応 力度, 横軸には拘束圧を示している. 拘束圧の值として, 室内付着 力試験の場合には試験体（耐荷体と注入材による試験体）に作用さ せた $\sigma_{3}$ の值を，引抜試験の場合には定着体（注入材）に作用する 地盤の拘束圧 $\sigma \mathrm{h}$ の值を用いている.ただし，定着地盤が砂磁およ び砂地盤で $\mathrm{N}$ 值 50 以上の場合には $\tau \mathrm{u}=\sigma \mathrm{h}$ となることから， $\sigma_{\mathrm{h}}$ の 值には最大摩擦応力度を用いている。一方, 硬質粘土および軟岩の 場合には拘束圧の值として, 施工時における作用加圧力, 寸なわち ケーシング加圧注入時の加圧圧力 (地表での口元加圧力+定着体上端 までの注入材のヘッド圧）を用いることとした ${ }^{5)}$.なお，Fig.15に 示した最大付着応力度は定着体 $1 \mathrm{~m}$ 間の平均值ではなく, 耐荷体ひ ずみの計測断面間（約 $0.5 \mathrm{~m} ）$ での最大值を用いている.

$$
\begin{array}{r}
\text { 付 } \left.\tau_{c}=2000+2 \sigma_{3} \text { （ただし, 付 } \tau_{\mathrm{c}} \leqq 5000 \mathrm{kN} / \mathrm{m}^{2}\right) \\
\text { 記号, 付 } \tau_{\mathrm{c}} \text { : 極限付着応力度 }\left(\mathrm{kN} / \mathrm{m}^{2}\right) \\
\sigma_{3} \text { : 付着力試験での拘束圧 }\left(\mathrm{kN} / \mathrm{m}^{2}\right)
\end{array}
$$

今回実施した大口径アンカーでの引抜試験結果および筆者らが行 った一般口径アンカーでの試験結果を Fig. 15 に追記している. 一般 口径アンカーについても前述した大口径アンカーと同じ破壊推定を 行うと, 付着応力度が式(8)と同程度の場合には付着切れ, 式(8)を大 きく下回る場合には, 摩擦切れにより引抜きに至っている。したが って, 本アンカーでは Fig.15により, 引抜きに至る破壊モードを概 襍定できると考えられる.

引抜きに至る破壊モードとして付着切れまたは摩擦切れの二つの 破壊モードが想定されるが，今回の試験結果のように付着切れの場 合には引抜き後, 急激な荷重低下および変位増加が生じることから, 圧縮型地盤アンカーにおいては付着抵抗力には余裕を持たせ, 摩擦 切れが先行するように設計することが望ましいと言える.

\section{3 残留付着応力度と残留摩擦応力度}

定着地盤が砂碟の場合には付着切れにより引抜きに至ったと推定 されることから, 引抜き以降におけるアンカー挙動として,

Fig.16(a)には耐荷体の軸方向力分布, Fig.17 には付着応力度と耐荷 
体変位の関係を示した。シルト岩の場合には摩擦切れにより引抜き に至ったと推定されることから, Fig.16(b)には定着体の軸方向力分 布, Fig.18 には摩擦応力度と定着体变位の関係を示した。耐荷体変 位および定着体変位は概ね定着体の中間である 2 断面位置での変位 を用いている.

定着地盤が砂礫の場合，Fig.17 に示すように引抜き前後において (2)の状態から(3)几移行しており，定着体における付着応力度は大き く低下していることが分かる，その後，再載荷時には付着応力度は 再度増加し，(5)で付着すべりが生じていることが分かる．付着す心゙ り後の変位 $120 \sim 170 \mathrm{~mm}$ の範囲では付着応力度は一定值となる傾 向が認められることから，その時点での值を残留付着応力度と見な すと, 砂碟地盤では残留付着応力度は極限付着応力度の $1 / 3$ 程度と なっている.

一方, シルト岩の場合, Fig.18に示すように引抜き以降は定着体 変位の増加とともに摩擦応力度は徐々に低下寸るが, 変位 $115 \sim 155$ $\mathrm{mm}$ の範囲では摩擦応力度は概ね一定值となっていることから，そ の時点での值を残留摩擦応力度と見なすと, シルト岩では残留摩擦 応力度は引抜き時における極限摩擦応力度の $1 / 2$ 程度となる. また, この值は非排水せん断強さの $1 / 2$ に概水等しい.

シルト岩では Fig.16(b)に示すように, 定着体上端の 3 断面におけ る軸方向力は(5)の変位再急増時から(6)の最終計測時に増加している. また, Fig.4(c)に示したように載荷荷重も同様に(5)から (6)にかけて 徐々に増加している，そこで，定着体 3 断面における軸方向力を定 着体よりも上方の自由長部側の負担荷重とし，その值と引抜荷重と の差分を定着体の負担荷重として,それぞれの負担荷重を算定した. Fig.19に示すように(5)以降は, 自由長部側の負担荷重は定着体の負

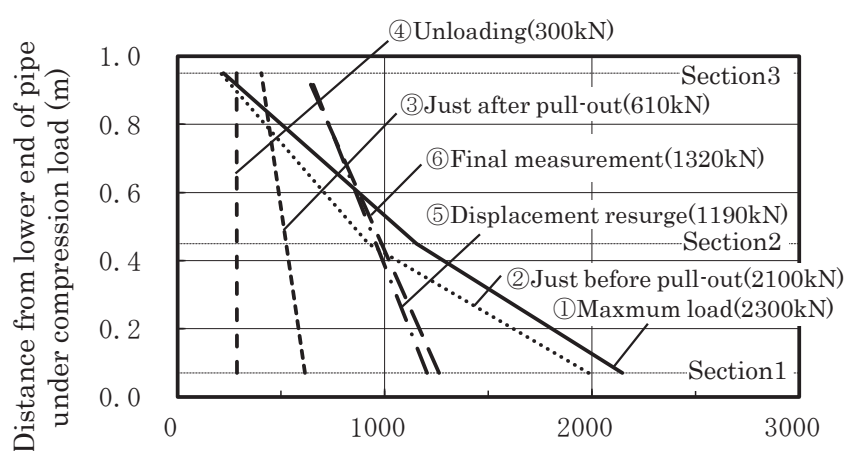

Axial force of pipe under compression load $(\mathrm{kN})$

(a)Gravel

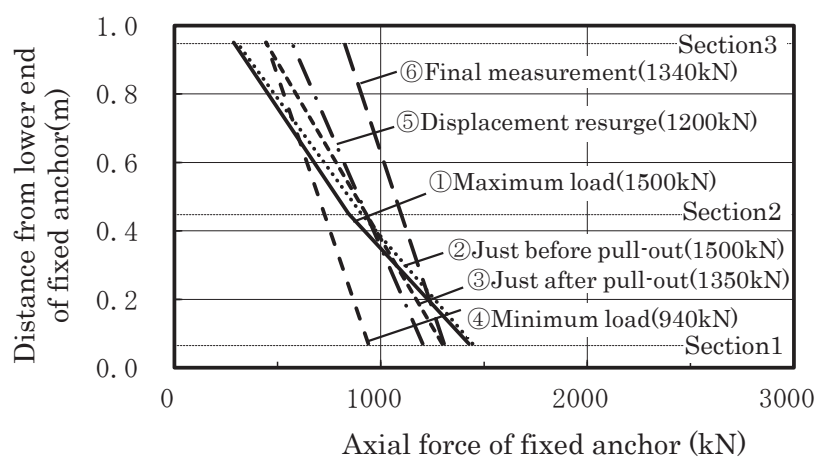

(b) Silt rock

Fig. 16 Axial force distribution of anchor after pull-out
担荷重よりも若干大きくなっており, また, 徐々に増加する傾向が 認められる.このことから, Fig.4(c)に示した耐荷体ひずみの最終計 測值である(6)以降を含め, (5)の状態から（7)の状態にかけて載荷荷重 が増加しているのは, 定着体から自由長部側への荷重伝達により, 摩擦抵抗力が発揮する範囲が自由長部側に徐々に拡大していくため であると推察される.ちなみに Fig.16(b)の軸方向力分布を自由長部 側に外挿（5)および(6)の外挿）する線と縦軸との交点が自由長部側 において摩擦抵抗力が発揮する上端であると考えると, 定着体上端 からの範囲は(5)では $1.7 \mathrm{~m}$, (6)では $2.4 \mathrm{~m}$ となり, 定着体 $1 \mathrm{~m}$ を加え ると引抜き以降における有効摩擦抵抗長は本アンカーの場合, $3 \mathrm{~m}$ 程度であると推定される。

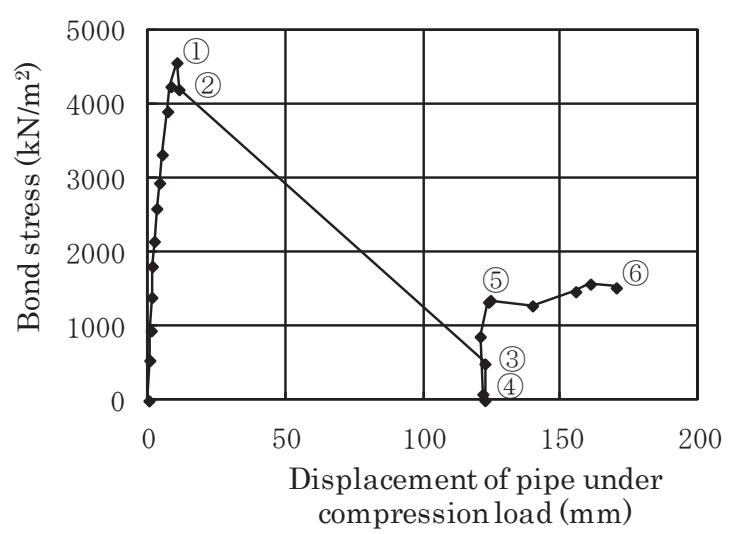

Fig. 17 Relationship between bond stress and displacement (soil type:gravel)

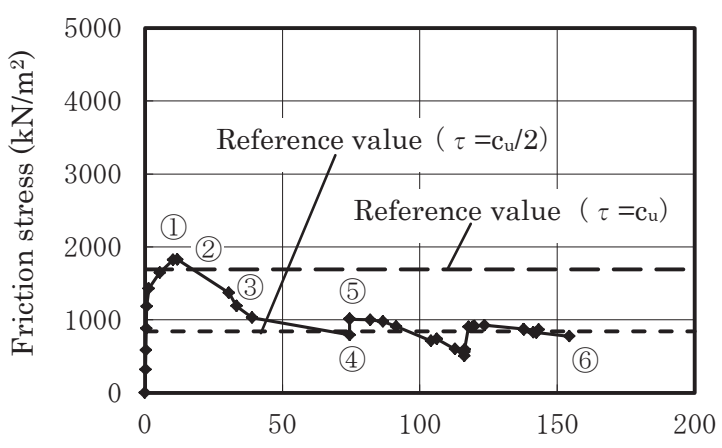

Displacement of fixed anchor ( $\mathrm{mm}$ ) Fig. 18 Relationship between friction stress and displacement (soil type:silt rock)

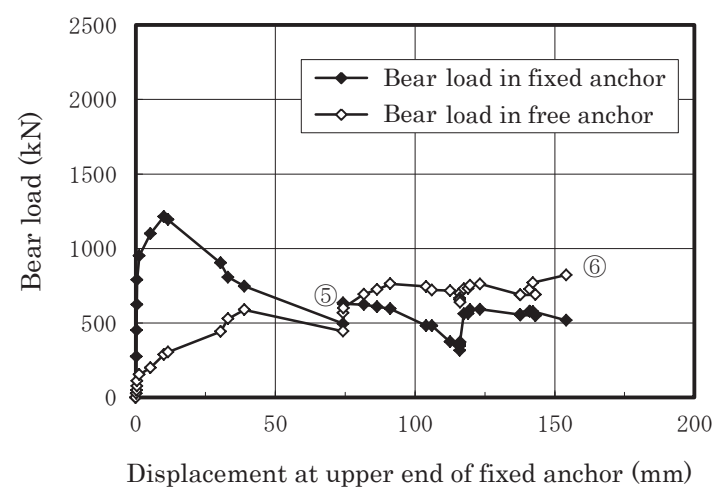

Fig. 19 Relationship between bear load and displacement of fixed anchor (soil type:silt rock) 


\section{5. まとめ}

大口径圧縮型地盤アンカーの摩擦応力度について, 引抜試験結果 を基に検討を行った。得られた知見は次のとおりである。

(1)定着地盤の種類に関わらず，アンカー頭部の荷重変位は引抜きに 至るまで概缐形関係にある，摩擦応力度は定着体下部側の值が 上部側の值より大きい状態で推移し，引抜き時には両者の值が等 しくなり，引抜きに至る.

(2)引抜き時における定着体変位は定着地盤の種類に関わらず， 10 $\mathrm{mm}$ 程度である．定着体の圧縮変形量は非常に小さく，定着体は 概ね剛体として挙動し, 抵抗する.引抜きに至るまでの摩擦応力 度と定着体変位の関係は，式(4)による双曲線で近似でき，シルト 岩を除き，概称類似した近似式となっている.

(3)引抜き時の破壊モードには摩擦切れまたは付着切れの 2 パターン が見られる. 定着体における区間付着応力度が式(8)の值を大きく 下回って引抜きに至った場合には摩擦切れ, 式(8)の值と同程度と なり引抜きに至った場合には付着切れとなる傾向が見られた。た だし，付着切れの場合においても摩擦応力度は極限に近い状態に ある。

(4)極限摩擦応力度は既往の一般口径アンカーを含め, $\mathrm{N}$ 值との関係 で整理すると非常にばらつきが大きい結果となるが，定着地盤が 砂礫または砂の場合には孔内水平載荷試験における降伏圧, 一方, 硬質粘土または軟岩の場合には非排水せん断強さを用いることに より精度良く推定できる.

(5)定着地盤がシル卜岩の場合, 摩擦切れにより引抜きに至っており, 引抜き以降における残留摩擦応力度は極限摩擦応力度の $1 / 2$ 程度 であり, 非排水せん断強さの $1 / 2$ に概袮等しい，一方，砂碟の場 合には付着切れにより引抜きに至っており，引抜き以降における 残留付着応力度は極限付着応力度の $1 / 3$ 程度である.

(6)摩擦切れの場合，引抜荷重に急激な低下は見られないが，付着切 れの場合，引抜荷重の急激な低下および変位の急増が見られたこ とから, 設計上, 摩擦切れとなるように配慮することが望ましい なお，摩擦切れにより引抜きに至った後，定着体よりも上方の自 由長部側での摩擦抵抗力が増加する傾向が見られたが，引抜きに 至るまでの挙動を踏まえ，設計では定着体区間での摩擦応力度の みを考慮するのが適切である。

最後に，引抜試験における定着体の長さは $1 \mathrm{~m}$ であり，本報告は それらの試験に基づいた結果であることを付記しておく.

\section{謝辞}

本地盤アンカーの引抜試験の実施に際しては，多くの方から助言 をいただきました。ここに記して深く感謝申し上げます。

\section{参考文献}

1) $\mathrm{AIJ}$ : Recommendations for the Design and Construction of Ground Anchorages, pp.40-42, 2001.1 (in Japanese)

日本建築学会 : 建築地盤アンカー設計施工指針・同解説,pp.40-42,2001.1

2) AIJ : Recommendations for the Design and Construction of Ground Anchorages,pp.94-98,2001.1 (in Japanese)

日本建築学会 : 建築地盤アンカー設計施工指針・同解説,pp.94-98,2001.1

3) Y. Katsura, M. Aoki and T. Mori : A Ultimate Resistance of A New Permanent Ground Anchorage System of Compression Type on Measurement Results, AIJ Journal of Technology and Design, No.1, pp.133-138, 1995.12（in Japanese）

桂豊, 青木雅路, 森利弘 : 実測に基づく圧縮型永久地盤アンカーの支持力 特性，日本建築学会技術報告集 第 1 号,pp.133-138,1995.12

4) T. Mori : Pulling Test of Permanent Ground Anchors of Compression Type Having A Large Diameter Settled in Sandy Soil, AIJ Journal of Technology and Design,Vol.18,No.38, pp.119-124,2012.2 (in Japanese) 森利弘：砂質土地盤に定着した大口径圧縮型地盤アンカーの引抜試験, 日本建築学会技術報告集 第 18 巻第 38 号,pp.119-124,2012.2

5) T. Mori and M. Endou : Pulling Test of Permanent Ground Anchors of Compression Type Having A Large Diameter Settled in Hard Clay and Soft Rock, AIJ Journal of Technology and Design,Vol.20,No.46, pp.917-920, 2014 (in Japanese)

森利弘, 遠藤正美 : 硬質粘土および軟岩に定着した大口径圧縮型地盤アン カーの引抜試験, 日本建築学会技術報告集 第 20 巻 第 46,pp.917-920, 2014.10

6) T. Mori, A Ogawa and N. Watanabe : Study of Permanent Ground Anchors Having A Large Diameter -Pulling Out Characteristic of Ground Anchors in Sandy Soil-, Kumagai Technical Research Report, Vol.70, pp.29-37, 2011.12 (in Japanese) 森利弘, 小川敦, 渡邊則雄 : 大口径本設地盤アンカー $(\mathrm{STK}-$ II アンカー工 法) の開発研究-砂質土地盤における引抜き抵抗特性-, 熊谷組技術研究報 告 第 70 号,pp.29-37,2011.12

7) N. Isemoto, Y. Katsura and T. Yamada : Bearing Capacity of Cast-in-place Concrete Pile (Part2: Relation between Skin-friction and Displacement),Summaries of Technical Papers of Annual Meeting Architectural Institute of Japan,B-1,pp.727-728,2000.9 (in Japanese) 伊勢本昇昭, 桂豊, 山田毅 : 場所打ちコンクリート杭の支持力性能（その 2) 周面摩擦力〜変位特性, 日本建築学会大会学術講演梗概集,B-1, pp.727-728, 2000.9

8) T. Mori : Relations with Frictional Stress and The Displacement of Permanent Ground Anchors of Compression Type Having A Large Diameter, Summaries of Technical Papers of Annual Meeting Architectural Institute of Japan,B-1, pp.619-620,2016.8 (in Japanese) 森利弘: 大口径圧縮型地盤アンカーにおける摩擦応力度と変位の関係, 日本建築学会大会学術講演梗概集, B-1,pp.619-620,2016.8

9) M. Iiri, N. Watanabe and T. Mori : Pulling Resistance of Permanent Ground Anchor of Compression Type over Two Strata (Cray and Gravel), Summaries of Technical Papers of Annual Meeting Architectural Institute of Japan,B-1,pp.481-482,2000.9 (in Japanese) 飯利昌人, 渡辺則雄, 森利弘 : 粘性土・砂礫互層地盤における圧縮型永久 地盤アンカーの引抜き抵抗, 日本建築学会大会学術講演梗概集,B-1, pp.481-482,2000.9 


\section{EVALUATION OF FRICTIONAL STRESS OF COMPRESSIVE TYPE GROUND ANCHOR WITH A LARGE DIAMETER BASED ON PULLING TESTS}

\section{Toshihiro MORI ${ }^{* 1}$ and Masaharu ENDO ${ }^{* 1}$}

${ }^{* 1}$ Basic Technology Research Office, Technical Research \& Development Institute, Technical Division, Kumagaigumi Co., Ltd., M.Eng.

We have evaluated the frictional stress of ground anchor of compression type with a large diameter based on the pulling test.

The concluding remarks of these test results are as follows:

1) The relationship between the pull-out load and displacement at the anchor head is roughly linear till the pull-out of anchor. In addition, the frictional stress of the lower side of the fixed anchor develops, larger than that of the upper side in the process of loading. Finally they become equal at the time of pull-out.

2) Regardless of soil type, the displacement of fixed anchor at the time of pull-out is about $10 \mathrm{~mm}$. The relationship between the frictional stress and displacement can be approximated by a hyperbola according to Equation (4), and these expressions are largely similar except for silt rock.

3) Two failure patterns were observed: the frictional resistance reaches the limit or the bond resistance reaches the limit. When the bond stress is much lower than the value of the Formula (8), the former pattern was observed. While the value was equivalent to the value of the Formula (8), the latter pattern was observed.

4) When the ultimate friction stress is analyzed in relation to SPT-N value, the variation is very large. On the other hand, the ultimate friction stress is possible to be estimated accurately by using the value of yield pressure in borehole lateral load test in gravel and sand, and by using the undrained shear strength in hard clay and soft rock.

5) The bond resistance in gravel reaches the limit at the time of pull-out, and the residual bond stress is $1 / 3$ of the ultimate value. On the other hand, the frictional resistance in silt rock reaches the limit at the time of pull-out, and the residual friction stress is $1 / 2$ of the ultimate value and $1 / 2$ of the value of undrained shear strength.

6) There was no sharp decline in pulling load in the case of friction failure. But a sharp decline was observed in the case of bond failure. Hence friction failure is desirable as a design consideration. 